\title{
A post-merger hospital library collection survey and data analysis indicated better resource allocation and user satisfaction
}

\author{
Alexandra Davis, Risa Shorr, Kaitryn Campbell, and Jessie McGowan
}

\begin{abstract}
Library Services at The Ottawa Hospital was created as the result of a series of hospital mergers. Before the merger, the collections of the previous three libraries consisted primarily of print monographs and journals. The new collection meant better access to more resources. While Library Services' staff could see the many benefits of the changes, they wondered whether these benefits were successfully communicated to hospital staff and physicians and whether electronic access was being adopted. Through qualitative and quantitative data analysis, resource management issues resulting from the shift from paper textbooks and journals to electronic resources were reviewed. Of the users who had been at the hospital more than 5 years - approximately 50\% of those surveyed — half of them remained satisfied with the collection, and the other half said their satisfaction had increased. Of the users who had been at the hospital less than 5 years - the other $50 \%$ of those surveyed $-29.3 \%$ remained satisfied with the collection, and $17.5 \%$ said their satisfaction had increased. Despite the increase in the number of resources and overall user satisfaction, misconceptions, confusion, and high expectations regarding e-resources still exist. The lessons learned and future goals identified in this survey will assist Library Services in its aim to clarify these issues by better educating users about online resources and by working more closely with various groups to facilitate access to our resources, both onsite and offsite.
\end{abstract}

\section{Setting}

This article follows a previous article in Bibliotheca Medica Canadiana describing the original merger of this library [1]. Library Services at The Ottawa Hospital (TOH) was created as the result of a series of hospital mergers. It supports a large teaching hospital serving the city of Ottawa, Ontario, and the surrounding area. TOH was formed in 1999 with the amalgamation of three hospitals: the Ottawa Civic, Ottawa General, and Riverside Hospitals. A fourth hospital, the Salvation Army Grace Hospital, was closed. In 2002, The Rehabilitation Centre (formerly part of the Royal Ottawa Hospital) merged with TOH. Recently, the Ottawa Regional Cancer Centre has also been merged with TOH.

A. Davis. ${ }^{1}$ The Ottawa Hospital, Civic Campus,

1053 Carling Avenue, D-1, Ottawa, ON K1Y 4E9,

Canada.

R. Shorr. The Ottawa Hospital, General Campus,

501 Smyth Road, Ottawa, ON K1H 8L6, Canada.

K. Campbell. Canadian Coordinating Office for Health

Technology Assessment (CCOHTA), 600-865 Carling

Avenue, Ottawa, ON K1S 5S8, Canada.

J. McGowan. Institute of Population Health, University

of Ottawa, 1 Stewart Street, room 206, Ottawa, ON

K1N 6N5, Canada.

${ }^{1}$ Corresponding author (e-mail: adavis@ottawahospital.on.ca).
Before the first merger, there were three separate libraries. These libraries remained and were merged to create the Library Services department of the new hospital. A reading room previously located at The Rehabilitation Centre was merged into the General Campus location of Library Services. Because of the recent merger with the Ottawa Regional Cancer Centre, its library, the Beattie Library, will also be added to the Library Services department; however, this paper will only focus on the original three-library merger.

\section{Background}

Library Services serves primarily staff from $\mathrm{TOH}$ and its affiliated research institute, the Ottawa Health Research Institute. It also provides services to third- and fourth-year medical students from the University of Ottawa. As well, it provides services to several regional hospitals and the local public health department.

Before the merger, the collections of the three libraries consisted primarily of print monographs and journals. TOH's objective for merging the libraries was to save money and increase efficiency in service delivery, including the elimination of duplicate journals and books. The library successfully convinced management not to reduce the budget if savings were found from the reduction or elimination of duplicate resources. The savings were used to sustain the present collection and purchase new resources. The number of 
Fig. 1. Number of journals before and after the merger.

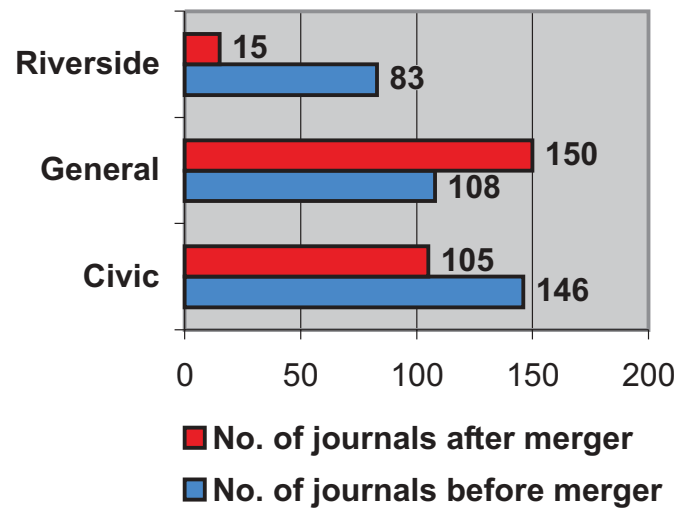

journals before and after the merger is shown in Fig. 1. During the 4-year period from the beginning of the merger, 62 duplicate titles were cut. This allowed Library Services to save more than CAN\$35000, which was allocated to new resources and the maintenance of the collection.

None of the libraries had electronic monographs before the merger, and only the Civic Campus Library had any electronic journals. The Civic Campus Library had access to five electronic journals; however, access was not centralized through a Web site or Intranet. After the merger, all three campuses had centralized access to 26 electronic monographs and approximately 1879 electronic journals via the Library Services Web site.

As the libraries merged, the collection budgets of each campus library were combined into one budget. Before the merger, the budgets of the two larger hospitals (the Ottawa Civic and Ottawa General Hospitals) were quite similar but allocated differently between monographs and journals. Figure 2 shows the pre-merger budget, which totalled CAN\$196 320.

From 1999 to 2003, the collection budget did not increase. However, CAN\$13 080 from the book budget was moved to another account to be used for electronic resources, decreasing the book budget from CAN\$48 000 to CAN\$35 000. Although there was no increase in the budget, the reduction in the duplication of books and journals meant that not only was there enough money to purchase the same number of new books, but there was also enough money to purchase additional titles.

The technical capabilities for accessing the collection in each library before and after the merger were reviewed. Before the merger, each library had different classification and cataloguing methods (Table 1). In each of the libraries, library users could not access the catalogue from outside the library. In addition, only one of the libraries had a Web site. After the merger, Library Services adopted one classification (Library of Congress) and cataloguing (DbText) method. The DbText system was accessible at all three campus libraries and on the Internet. A new bilingual Web site was created as part of the hospital's Web site to access the catalogue, online books, and online journals (www.ottawahospital. on.ca/library).

All of these challenges and changes meant that the three libraries now functioned differently as Library Services. This left Library Services' staff questioning how library us-
Fig. 2. Collection budget (pre-merger).

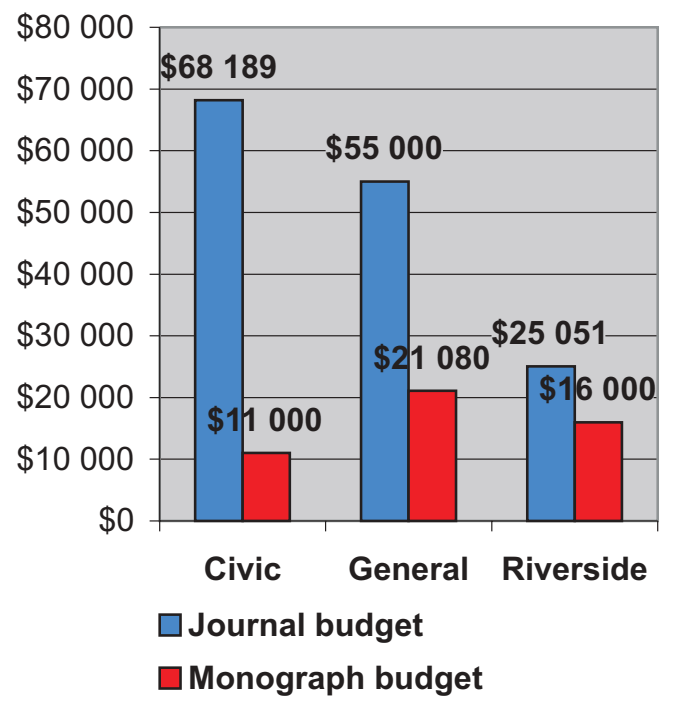

Table 1. Library classification and cataloguing methods.

\begin{tabular}{lll}
\hline Location & $\begin{array}{l}\text { Classification } \\
\text { schemes }\end{array}$ & Catalogue \\
\hline Civic Campus & NLM & SydneyPlus \\
General Campus & LC & $\begin{array}{c}\text { DbText and Inmagic } \\
\text { Riverside Campus }\end{array}$ \\
& NLM & $\begin{array}{c}\text { InMagic (manual } \\
\text { circulation) }\end{array}$ \\
\hline
\end{tabular}

Note: NLM, National Library of Medicine; LC, Library of Congress.

ers felt about the shift from paper textbooks and journals to electronic resources and the increased access to materials. Other libraries have seen that the biggest benefit of a merger is access to a larger collection of resources [1-5]. While Library Services' staff could see the many benefits of the changes, they wondered whether these benefits were successfully communicated to hospital staff and physicians and whether electronic access was being adopted.

\section{Methods}

Through qualitative and quantitative data analysis, resource management issues resulting from the shift from paper textbooks and journals to electronic resources were reviewed. This analysis was performed through the examination of two key resources: (1) the results of a qualitative questionnaire and (2) the data analysis of retrospective and current collection development reports.

A structured 10-question survey was developed by three of the authors ( $\mathrm{RS}, \mathrm{AD}$, and $\mathrm{KC}$ ) to record users' opinions on the impact of the new collection development strategy to reduce print resources and acquire more electronic resources (Appendix A). The questionnaire was tested and then submitted to the Ottawa Hospital Research Ethics Board as part of the study protocol. After the protocol was approved, the two-page questionnaire and one-page information sheet (Appendix B) were made available (in English and French) to the 9100 staff and physicians of TOH in paper and electronic formats. Respondents were offered the choice of re- 
Fig. 3. Respondent distribution by profession.

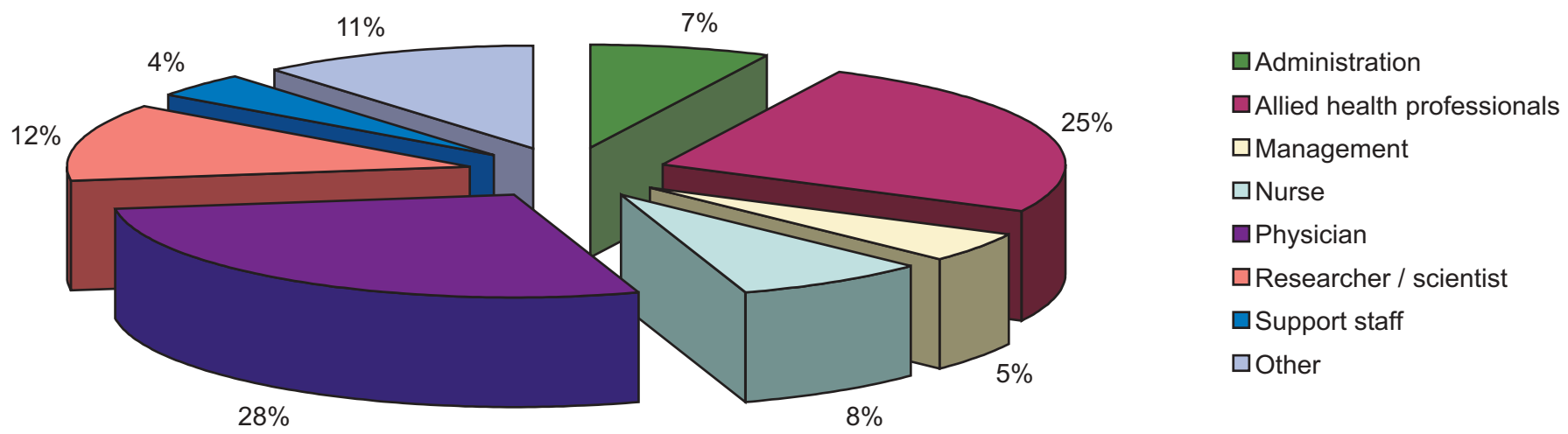

plying using one of the following methods during a 4-week period in March-April 2003: responding to an e-mail message, responding to a pop-up notification on the Library Services home page, or filling out a print copy of the form received either in the internal mail or picked up in one of the libraries.

The initial goal of 369 surveys (9 100 total TOH staff, 5\% margin of error, $95 \%$ confidence interval $(\mathrm{CI})=369$ surveys $)$ was not reached. However, a total of 225 surveys were received (9 100 total TOH staff, 5.5\% margin of error, $90 \%$ $\mathrm{CI}=219$ surveys). Total responses for each question were counted, and comments, where applicable, were transcribed. Results are represented as a percentage of the total number of responses.

To gain an empirical understanding of the specific resources available at Library Services locations, pre- and post-merger, historical collection data was obtained from archived collection reports. The goal was to obtain a quantitative view of whether access had improved. Current data on the present collection, up until 31 March 2003, was taken from the Library Services' catalogue in DB/Text DBMS.

Data regarding the total number of print monographs, print journals, electronic monographs, and electronic journals, pre- and post-merger, at all three campuses were collected. These numbers were calculated through a simple count of each type of resource. These resources have been previously described in the background section of this paper.

\section{Results and discussion}

The survey results fell into one of three broad areas: users' personal information, users' level of satisfaction with the collection, and issues surrounding online access to the collection. Approximately $75 \%$ of those surveyed used the library at least once per month, with $4 \%$ of respondents having never used the collection. Physicians and allied health professionals together accounted for $53 \%$ of respondents (Fig. 3).

Half of survey respondents had worked at $\mathrm{TOH}$ for more than 5 years, and therefore only these respondents had been employed by the hospital both pre- and post-merger. As shown in Table 2, TOH physicians and staff had a high level of technical competency regarding online access of resources. Since the merger, users at each of the three campuses had access to more resources. The transition to online access necessitated a shift in the conceptualization of the library for its staff and users. Both groups dealt with the is-
Table 2. Technical competencies regarding online access.

\begin{tabular}{ll}
\hline Issue & $\begin{array}{l}\% \text { of } \\
\text { respondents }\end{array}$ \\
\hline Find online material somewhat or very convenient & 90 \\
Find it easy or very easy to access material online & 74 \\
Have read or printed material from online resource & 73 \\
Would use electronic version of resource over paper & 62 \\
\hline
\end{tabular}

Fig. 4. Change in collection satisfaction.

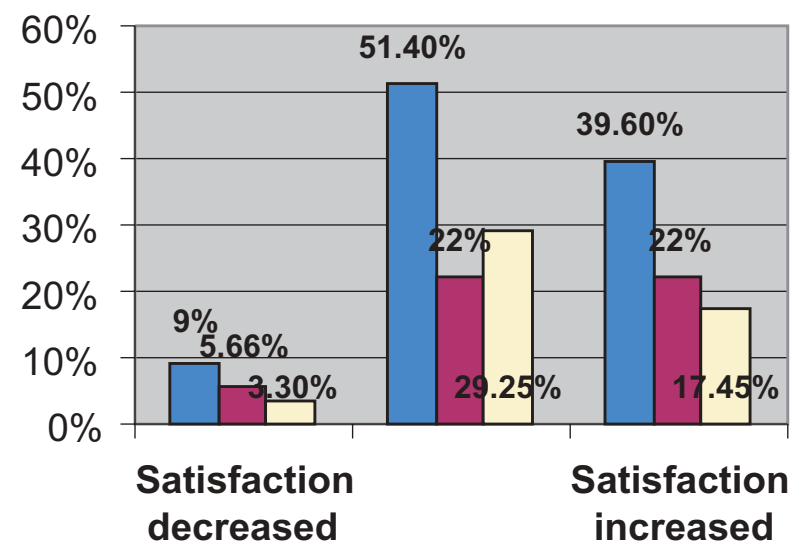

All users

Users over 5 years

Users less than 5 years

sues of permanent access to resources, ease of e-resource use, and comfort with technology, although overall satisfaction with access was high.

Regarding user satisfaction, two main areas were examined: (1) the change in the users' collection satisfaction pre- and post-merger and (2) the users' current satisfaction level (Fig. 4).

Of the users who had been at the hospital over 5 years approximately $50 \%$ of those surveyed - slightly fewer than half of them remained satisfied with the collection and satisfaction increased for the other half. Only $5.7 \%$ of these users said their satisfaction had diminished. Possible reasons for dissatisfaction could be attributed to the cancellation and relocation of print subscriptions and books to other campuses. Also, many users had difficulty adapting to resources that were once in print now being available only electronically. 
Table 3. Lessons learned.

\begin{tabular}{|c|c|}
\hline Situation & Reaction \\
\hline Journal and book budgets remained the same & $\begin{array}{l}\text { Budgets were pooled and funds were redistributed, resulting in immense } \\
\text { collection growth }\end{array}$ \\
\hline Decision was made not to duplicate journal titles & $\begin{array}{l}\text { Duplicate titles removed among three campus collections, resulting in more } \\
\text { funds for other titles (some titles were deemed necessary to duplicate) } \\
\text { Library Services entered into consortia, resulting in less costly resources }\end{array}$ \\
\hline One classification and cataloging system was chosen & Shared catalogue created, diminishing duplication of cataloguing efforts \\
\hline Only one pre-merger library had a Web site & $\begin{array}{l}\text { Single Web site created for resource access, diminishing duplication of site } \\
\text { maintenance required. Management of the entire hospital Web site was } \\
\text { placed under the management of the Library Services Director }\end{array}$ \\
\hline
\end{tabular}

Table 4. Future goals.

\begin{tabular}{ll}
\hline Goal & Potential solution \\
\hline Continue to increase users' satisfaction regarding current collection & Solicit feedback from departments regarding resource needs \\
$\begin{array}{l}\text { Provide access to more online material } \\
\text { Facilitate better access to online material }\end{array}$ & Investigate the possibility of more online resources \\
Enable remote access to more users & Encourage purchase of proxy server \\
Engage in more cooperative resource sharing & Encourage purchase of proxy server \\
Gauge users' satisfaction with the services provided from Library Services & Investigate possibility of additional consortia \\
\hline
\end{tabular}

This change was too sudden for some users and caused confusion. Overall, however, the users who had been through the merger felt that the collection had improved or remained satisfactory.

Of the users who had been at the hospital less than 5 years - the other $50 \%$ of those surveyed $-29.3 \%$ remained satisfied with the collection, and $17.5 \%$ said their satisfaction had increased. Only 3\% of this user group said their satisfaction had diminished. Possible reasons for dissatisfaction could be that these users were coming from other institutions, where the resources were more abundant and already electronically advanced. These users may have had higher expectations that could not be met, given the current status of Library Services. Also, many people replied on their survey that they answered "not currently satisfied with the collection" because they felt that "there was always room for improvement". Even though the merger had not affected this user group, they still regarded the collection favourably.

When asked to comment about the ease, convenience, or overall satisfaction regarding Library Services' electronic resources, the majority of users' comments were positive. However, some users reported confusion or frustration in gaining access, with comments such as it was "sometimes confusing trying to get material online and may be faster to get a paper copy"; one user had been "sometimes frustrated by the convoluted access to e-journal passwords". There is also a clear opportunity for Library Services to offer users some education and (or) guidance regarding copyright misconceptions, as some users reported that the features they most enjoyed regarding e-access was being able to integrate electronic documents "into quick presentations for teaching", or "saving documents to [their] hard-drive". Additionally, Library users' expectations were quite high regarding what sort of online access Library Services could provide, as evidenced by suggestions such as, "what about linking to the University of Ottawa Heart Institute [an agency funded separately from $\mathrm{TOH}]$ e-journals thru $\mathrm{TOH}$ ?"

\section{Conclusions}

Combining the collection from three hospital libraries into one was a challenging experience. With the successful initial merger and re-organization of the collection, and a move to more resources in electronic format and fewer in print, users can now access more resources from their desktops. Through the analysis of the data collected during this study, a number of lessons were learned (Table 3). A number of goals on which to focus Library Services efforts in the future were also identified (Table 4).

Despite the increase in the number of resources and overall user satisfaction, misconceptions, confusion, and high expectations regarding e-resources still exist. The lessons learned and future goals identified will assist Library Services in its aim to clarify these issues by better educating users about online resources and by working more closely with various groups to facilitate access to our resources, both onsite and offsite.

\section{References}

1. McGowan J. Merging hospital libraries: challenges and successes. Bibliotheca Medica Canadiana. 2001;22(4):152-4.

2. Kilfoil A. Regionalizing hospital library services in New Brunswick. Bibliotheca Medica Canadiana. 1995;16(4):164-6.

3. Alzinger S. Regionalizing and restructuring in British Columbia: the Simon Graser Health Region experience. Bibliotheca Medica Canadiana. 1997;19(2):70-1.

4. Kober G, Lamont E. Planning for library services in a merged hospital environment: the McGill University Health Centre experience. Bibliotheca Medica Canadiana. 1999;21(1)226-8.

5. Regenberg PB, Joyce MK, Moeller K, Ratner J. Surviving a merger: how four hospital libraries created a unified system. $J$ Med Libr Assoc. 2002;90(1):98-100. 


\section{Appendix A}

\section{TOH Staff \& Physician Survey from Library Services}

We are very pleased you are taking the time to fill out our survey. Please answer the following questions as accurately as possible.

1) Which department(s)/division(s) do you work in?

2) Please circle the category which best matches your job title:

Administration Allied Health Professional Management Nurse

Physician Researcher/Scientist Support Staff Other:

3) Which of the 3 campuses is your home campus (check 1)?

Civic General Riverside

4) How often do you use Library Services' print and electronic collection of books and/or journals (check 1)?

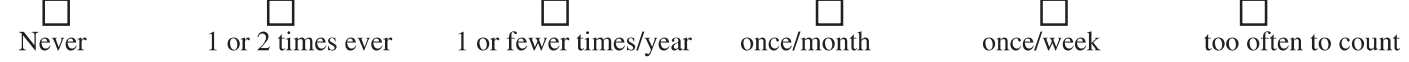

5) How long have you been using Library Services (check 1)?

over 10 years between 5-9 years $\quad$ between $1-4$ years $\quad \square$ year

6) Since you started using Library Services, has your level of satisfaction with the available books and/or journals (check 1):

Increased remained the same diminished

7) Are you currently satisfied with the selection of books and/or journals you have access to (print \& online) through Library Services (check 1)?
$\square$
$\square$
Don't care

a) If not, why not (circle all that apply)?

Not enough/No resources in my specialty

Don't know how to navigate/use website

Resources are not current

Other:

8) Have you ever printed/read an article from one of the electronic books or journals offered by Library Services through our website (check 1)?

$\square$

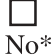

*If no, please skip this question and continue on to question 9).

If yes:

a) How would you rate the ease of accessing the information you were looking for (e.g. I found the information without any trouble or frustration, so it was very easy.) (circle 1)?

$\begin{array}{lllll}5 & 4 & 3 & 2 & 1 \\ \text { Very easy } & \text { Easy } & \text { Neutral } & \text { Difficult } & \text { Very difficult }\end{array}$

Over 
b) How would you rate the level of convenience in using our electronic journals and/or books (e.g. I didn't have to leave my office, so it was very convenient.) (circle 1)?
5
Very convenient Somewhat convenient Neutral
2
1
Very inconvenient

c) How would you rate your overall level of satisfaction with using our electronic books and/or journals (circle 1)?

$\begin{array}{lllll}5 & 4 & 3 & 2 & 1 \\ \text { Very satisfied } & \text { Somewhat satisfied } & \text { Neutral } & \text { Somewhat dissatisfied } & \text { Very dissatisfied }\end{array}$

d) Do you have any other comments about the ease, convenience or your overall satisfaction regarding our electronic resources?

9) If you had a choice between using an electronic or paper format of a book and/or journal, which would you choose (check 1)?

electronic paper don't care

a) Why would you choose this format (circle all that apply)?

More convenient

Just prefer this format

Don't know

Prefer to read away from my computer

Other:

10) Circle any of the following sites to which you have gone to use books and/or journals instead of using Library Services' collection, while employed at TOH (circle all that apply):

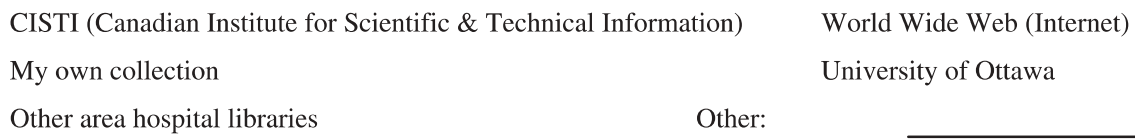

Other area hospital libraries

Other:

a) Why have you used these sites instead of using Library Services' collection (circle all that apply)?

Not enough time to go to Library Services Better selection elsewhere

Didn't know we had a library

Everything I need is free on the Internet

Other:

Thank-you very much! The results of this survey will be available at all 3 Library Services locations in May.

Yours,

Library Services Staff 


\section{Sondage des Services de bibliothèque auprès des employés et des médecins}

Nous sommes très heureux que vous acceptiez de remplir ce sondage. Veuillez répondre aux questions le plus précisément possible.

1) Dans quel(s) service(s)/division(s) travaillez-vous?

2) Veuillez encercler la catégorie qui correspond le mieux au titre de votre poste :

$\begin{array}{llll}\text { Administration } & \text { Professionnel(le) paramédical(e) Direction } & \text { Infirmier(ère) } \\ \text { Médecin } & \text { Chercheur/scientifique } & \text { Personnel de soutien } & \text { Autre : }\end{array}$

3) Quel est votre campus principal (cochez une seule case)?
Le Civic
Le Général
Le Riverside

4) À quelle fréquence utilisez-vous la collection sur papier et électronique de livres/revues des Services de bibliothèque (cochez une seule case)?
Jamais
1 ou 2 fois à ce jour
Pas plus d'une fois l'an
Une fois par mois
Une fois par semaine
Très fréquemment

5) Depuis combien de temps utilisez-vous les Services de bibliothèque (cochez une seule case) ?
Plus de 10 ans
Depuis 5 à 9 ans
Depuis un à quatre ans
Depuis moins d'un an

6) Depuis que vous avez commencé à utiliser les Services de bibliothèque, votre degré de satisfaction au sujet des livres/revues disponibles (cochez une seule case) :
a augmenté
est demeuré le même
a diminué

7) Êtes-vous présentement satisfait(e) de la sélection de livres/revues à laquelle vous avez accès (sur papier ou en ligne) par l'entremise des Services de bibliothèque (cochez une seule case) ?
Oui
Non
Indifférent(e)

a) Dans la négative, pour quelle raison (encerclez toutes les réponses qui s'appliquent)?

Pas assez/pas de ressources dans ma spécialité

Ne sait pas comment naviguer sur le site Web ou l'utiliser
Les ressources ne sont pas à jour

Autre : 
8) Avez-vous déjà imprimé/lu un article de l'un des livres ou l'une des revues offerts sur le site Web des Services de bibliothèque (cochez une seule case) ?

$\square$ Oui $\quad \square$ Non*

*Dans la négative, veuillez sauter la question suivante et passer à la question 9).

Dans l'affirmative :

a) Comment classeriez-vous l'accès aux renseignements que vous cherchez (p. ex. : je les trouve très facilement, sans problème ni frustration.) (encerclez une seule case) ?

$\begin{array}{lllll}5 & 4 & 3 & 2 & 1 \\ \text { Très facile } & \text { Facile } & \text { Neutre } & \text { Difficile } & \text { Très difficile }\end{array}$

b) Comment classeriez-vous le niveau d'inconvénients que représente l'utilisation de nos revues/livres électroniques (p. ex. : je n'ai pas à quitter mon bureau, alors c'est très pratique) (encerclez une seule case) ?

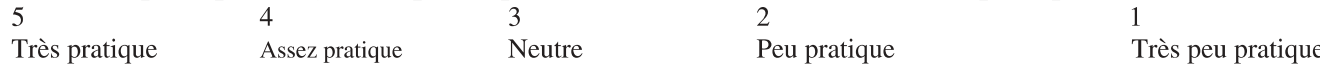

c) Dans l'ensemble, quel est votre degré de satisfaction par rapport à l'utilisation de nos livres/revues électroniques (encerclez une seule case)?

$\begin{array}{lllll}5 & 4 & 3 & 2 & 1 \\ \text { Très satisfait(e) } & \text { Assez satisfait(e) } & \text { Neutre } & \text { Peu satisfait(e) } & \text { Très peu satisfait(e) }\end{array}$

d) Avez-vous d'autres commentaires au sujet de la facilité, de l'aspect pratique ou de votre satisfaction générale au sujet de nos ressources électroniques?

9) Si vous aviez le choix entre l'utilisation d'une revue/d'un livre en format électronique ou sur papier, quel seraitil (cochez une seule case)?

Électronique Sur papier Peu importe

a) Pourquoi choisiriez-vous ce format (encerclez toutes les réponses qui s'appliquent)?

$\begin{array}{ll}\text { Plus pratique } & \text { Je préfère tout simplement ce format } \\ \text { Ne sais pas } & \text { Je préfère lire les documents ailleurs qu'à l'ordinateur }\end{array}$

Autre :

10) Encerclez l'un des sites suivants où vous avez consulté des livres/revues au lieu d'avoir recours à la collection des Services de bibliothèque (encerclez toutes les réponses qui s'appliquent) :

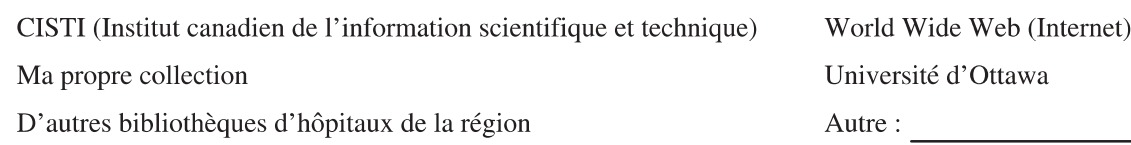

D'autres bibliothèques d'hôpitaux de la région

Autre :

a) Pourquoi avez-vous utilisé d'autres sites plutôt que de consulter la collection des Services de bibliothèques (encerclez toutes les réponses qui s'appliquent)?

Pas le temps de me rendre aux Services de bibliothèque Meilleure sélection ailleurs

Ne savais pas que nous avions une bibliothèque

Tout ce dont j'ai besoin est gratuit sur l'Internet

Autre :

Merci beaucoup ! Les résultats de ce sondage seront disponibles en mai dans les trois emplacements des Services de bibliothèque.

Bien vôtre,

Le personnel des Services de bibliothèque 


\section{Appendix B}

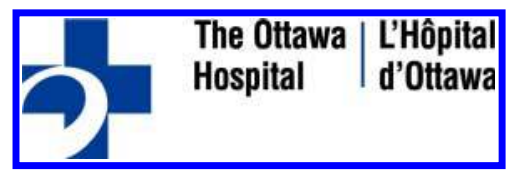

Information Sheet

\section{Resource Management in the Face of Hospital Amalgamation}

Background of Study - Library Services is conducting a study in order to evaluate the impact of the hospitals' amalgamation on our collection of books and journals.

Purpose and Design - Our objective is to evaluate the access to resources at all three campuses before and after the merger. In addition, we look at the impact of the changes on our users. Along with the results of this survey of TOH/OHRI staff and physicians, we are comparing the number of resources to which each campus had access preand post-amalgamation in order to obtain a quantitative view of whether access has improved.

Survey Procedure - We are asking for your participation as a member of TOH/OHRI staff, so that we may incorporate your views in our results. This is the only questionnaire we will be asking staff and physicians to answer. It will take approximately 5 minutes. You may skip any questions you are not comfortable answering.

Voluntary Participation - Answering this questionnaire is completely voluntary.

\section{Questions about the Study}

Please contact any of the investigators below, should you have any questions about this survey or its results:

$\begin{array}{lll}\text { Kaitryn Campbell } & \text { Alexandra Davis } & \text { Risa Shorr } \\ \text { Librarian, Riverside Campus } & \text { Librarian, Civic Campus } & \text { Librarian, General Campus } \\ 738-8400 \text { x. } 88230 & 798-5555 \text { x.14459 } & 737-8899 \times .72811\end{array}$

\section{Consent}

I have read this Information Sheet (or have had this document read to me), and have had an opportunity to ask any questions I had about the study.

My questions and/or concerns have been answered to my satisfaction and I agree to participate in this study.

A copy of the Information Sheet will be provided to me should I want to review the information at a later date, if I need to contact someone about the study or my participation in the study, or simply for my records.

\section{Signature}

Participant's Name (print)

Investigator/Delegate's Name (print)
Participant's Signature

Investigator/Delegate's Signature 


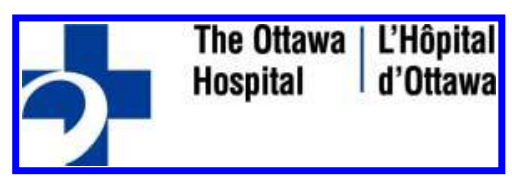

\section{Fiche d'information \\ Gestion des ressources face à l'amalgamation des hôpitaux}

Contexte de l'étude - Les Services de bibliothèque mènent une étude afin de déterminer les répercussions de l'amalgamation des hôpitaux sur sa collection de livres et de revues.

Objectif et intention - Notre objectif consiste à étudier l'accès aux ressources dans les trois campus, avant et après la fusion. Nous examinons aussi les conséquences des changements sur nos usagers. Nous comparons, en plus de l'analyse des résultats de ce sondage auprès des employés et des médecins de L'HO/L'IRSO, la quantité de ressources auxquelles chaque campus avait accès, avant et après l'amalgamation, en vue d'obtenir un aperçu quantitatif de l'amélioration de l'accès, le cas échéant.

Procédure du sondage - Nous vous demandons de participer au sondage en tant que membre du personnel de L'HO/L'IRSO, afin d'incorporer votre opinion dans nos résultats. C'est le seul questionnaire auquel nous demandons au personnel et aux médecins de répondre. Il ne faut qu'environ cinq minutes environ pour ce faire. Vous pouvez sauter les questions auxquelles vous hésitez à répondre.

Participation volontaire - Vous êtes entièrement libre de répondre à ce questionnaire.

\section{Questions au sujet de l'étude}

N'hésitez pas à communiquer avec l'une des responsables suivantes si vous avez des questions au sujet de ce sondage ou de ses résultats :

Kaitryn Campbell

Bibliothécaire,

Campus Riverside

$738-8400$, poste 88230

\author{
Alexandra Davis \\ Bibliothécaire, \\ Campus Civic \\ $798-5555$, poste 14459
}

Risa Shorr

Bibliothécaire,

Campus Général

737-8899, poste 72811

\section{Consentement}

J'ai lu cette fiche d'information (ou quelqu'un me l'a lue), et j'ai pu poser des questions au sujet de l'étude.

On a répondu de manière satisfaisante à mes questions ou préoccupations et je consens à participer à cette étude.

On me fournira une copie de la feuille d'information si je souhaite consulter à nouveau ces renseignements ultérieurement, si je dois communiquer avec l'une des responsables au sujet de l'étude ou de ma participation ou tout simplement si je veux la conserver dans mes dossiers.

\section{Signature}

Nom du(de la) participant(e) (en majuscules)

Nom de la responsable/de son(sa) remplaçant(e) (en majuscules)
Signature du(de la) participant(e)

Nom de la responsable/de son(sa) remplaçant(e) (en majuscules) 